\title{
An Introduction to Mineralogy
}

\author{
Cumhur Aydinalp \\ Uludag University, Bursa, \\ Turkey
}

\section{Introduction}

The science of mineralogy is a branch of the earth sciences that is concerned with studying minerals and their physical and chemical properties. Within mineralogy there are also those who study how minerals are formed, where they are geographically located, as well as their potential uses. Like many sciences, mineralogy has its origins in several ancient civilizations, and it has been concerned primarily with the various methods of classification of minerals for most of its history. Modern-day mineralogy has been expanded by advances in other sciences, such as biology and chemistry, to shed even more light on the nature of the materials that form the earth we live on.

The ancient Greek philosopher Aristotle was one of the first people to theorize extensively about the origins and properties of minerals. His ideas were new and advanced for the time, but he and his contemporaries were largely incorrect in their assumptions. For example, it was a widely held belief in ancient Greece that the mineral asbestos was a kind of vegetable. Nevertheless, these ancient theories provided a starting point for the evolution of mineralogy as we have come to know it. It was not until the 16th century that mineralogy began to take a form that is recognizable to us, largely thanks to the work of German scientist Georgius Agricola.

- For example, it was a widely held belief in ancient Greece that the mineral asbestos was a kind of vegetable. Nevertheless, these ancient theories provided a starting point for the evolution of mineralogy as we have come to know it. It was not until the 16th century that mineralogy began to take a form that is recognizable to us, largely thanks to the work of German scientist Georgius Agricola.

\section{Definition of mineral}

A mineral is a naturally-occurring, homogeneous solid with a definite, but generally not fixed, chemical composition and an ordered atomic arrangement. It is usually formed by inorganic processes.

Let's look at the five parts of this definition:

1. "Naturally occurring" means that synthetic compounds not known to occur in nature cannot have a mineral name. However, it may occur anywhere, other planets, deep in the earth, as long as there exists a natural sample to describe. 
2. "Homogeneous solid" means that it must be chemically and physically homogeneous down to the basic repeat unit of the atoms. It will then have absolutely predictable physical properties (density, compressibility, index of refraction, etc.). This means that rocks such as granite or basalt are not minerals because they contain more than one compound.

3. "Definite, but generally not fixed, composition" means that atoms, or groups of atoms must occur in specific ratios. For ionic crystals (i.e. most minerals) ratios of cations to anions will be constrained by charge balance, however, atoms of similar charge and ionic radius may substitute freely for one another; hence definite, but not fixed.

4. "Ordered atomic arrangement" means crystalline. Crystalline materials are threedimensional periodic arrays of precise geometric arrangement of atoms. Glasses such as obsidian, which are disordered solids, liquids (e.g., water, mercury), and gases (e.g., air) are not minerals.

5. "Inorganic processes" means that crystalline organic compounds formed by organisms are generally not considered minerals. However, carbonate shells are minerals because they are identical to compounds formed by purely inorganic processes.

An abbreviated definition of a mineral would be "a natural, crystalline phase". Chemists have a precise definition of a phase. A phase is that part of a system which is physically and chemically homogeneous within itself and is surrounded by a boundary such that it is mechanically separable from the rest of the system. The third part of our definition of a mineral leads us to a brief discussion of stoichiometry, the ratios in which different elements (atoms) occur in minerals. Because minerals are crystals, dissimilar elements must occur in fixed ratios to one another. However, complete free substitution of very similar elements (e.g., $\mathrm{Mg}^{+2}$ and $\mathrm{Fe}^{+2}$ which are very similar in charge (valence) and radius is very common and usually results in a crystalline solution (solid solution). For example, the minerals forsterite $\left(\mathrm{Mg}_{2} \mathrm{SiO}_{4}\right)$ and fayalite $\left(\mathrm{Fe}_{2} \mathrm{SiO}_{4}\right)$ are members of the olivine group and have the same crystal structure, that is, the same geometric arrangement of atoms. $\mathrm{Mg}$ and $\mathrm{Fe}$ substitute freely for each other in this structure, and all compositions between the two extremes, forsterite and fayalite, may occur. However, $\mathrm{Mg}$ or Fe do not substitute for $\mathrm{Si}$ or $\mathrm{O}$, so that the three components, $\mathrm{Mg} / \mathrm{Fe}, \mathrm{Si}$ and $\mathrm{O}$ always maintain the same 2 to 1 to 4 ratio because the ratio is fixed by the crystalline structure. These two minerals are called endmembers of the olivine series and represent extremes or "pure" compositions. Because these two minerals have the same structure, they are called isomorphs and the series, an isomorphous series.

In contrast to the isomorphous series, it is also common for a single compound (composition) to occur with different crystal structures. Each of these structures is then a different mineral and, in general, will be stable under different conditions of temperature and pressure. Different structural modifications of the same compound are called polymorphs. An example of polymorphism is the different minerals of $\mathrm{SiO}_{2}$ (silica); alphaquartz, beta-quartz, tridymite, cristobalite, coesite, and stishovite. Although each of these has the same formula and composition, they are different minerals because they have different crystal structures. Each is stable under a different set of temperature and pressure conditions, and the presence of one of these in a rock may be used to infer the conditions of formation of a rock. Another familiar example of polymorphism is graphite and diamond, two different minerals with the same formula, C (carbon). 
Glasses (obsidian), liquids, and gases however, are not crystalline, and the elements in them may occur in any ratios, so they are not minerals. So in order for a natural compound to be a mineral, it must have a unique composition and structure (Blackburn \& Dennen, 1988).

\section{Composition of the earth's crust}

The earth's crust is composed of many kinds of rocks, each of which is an aggregate of one or more minerals. In geology, the term mineral describes any naturally-occurring solid substance with a specific composition and crystal structure. A mineral's composition refers to the kinds and proportions of elements making up the mineral. The way these elements are packed together determines the structure of the mineral. More than 3,500 different minerals have been identified. There are only 12 common elements (oxygen, silicon, aluminum, iron, calcium, sodium, potassium, magnesium, titanium, hydrogen, manganese, phosphorus) that occur in the earth's crust. All other naturally occurring elements are found in very minor or trace amounts. Silicon and oxygen are the most abundant crustal elements, together comprising more than 70 percent by weight (Rudnick \& Fountain, 1995). It is therefore not surprising that the most abundant crustal minerals are the silicates (e.g. olivine, $\mathrm{Mg}_{2} \mathrm{SiO}_{4}$ ), followed by the oxides (e.g. hematite, $\mathrm{Fe}_{2} \mathrm{O}_{3}$ ). Other important types of minerals include: the carbonates (e.g. calcite, $\mathrm{CaCO}_{3}$ ) the sulfides (e.g. galena, $\mathrm{PbS}$ ) and the sulfates (e.g. anhydrite, $\mathrm{CaSO}_{4}$ ). Most of the abundant minerals in the earth's crust are not of commercial value. Economically valuable minerals (metallic and nonmetallic) that provide the raw materials for industry tend to be rare and hard to find. Therefore, considerable effort and skill is necessary for finding where they occur and extracting them in sufficient quantities. Table 1 shows the elemental chemical composition of the Earth's crust in order of abundance (Lutgens \& Tarbuck, 2000).

\begin{tabular}{|c|c|c|}
\hline Element name & Symbol & $\begin{array}{c}\text { Percentage by weight of the } \\
\text { Earth's crust }\end{array}$ \\
\hline Oxygen & $\mathrm{O}$ & 46,6 \\
\hline Silicon & $\mathrm{Si}$ & 27,7 \\
\hline Aluminium & $\mathrm{Al}$ & 8,1 \\
\hline Iron & $\mathrm{Fe}$ & 5,0 \\
\hline Calcium & $\mathrm{Ca}$ & 3.6 \\
\hline Sodium & $\mathrm{Na}$ & 2,8 \\
\hline Potassium & $\mathrm{K}$ & 2,6 \\
\hline Magnesium & $\mathrm{Mg}$ & 2,1 \\
\hline All other elements & & 1,5 \\
\hline
\end{tabular}

Table 1. The elements in the Earth's crust (Lutgens \& Tarbuck, 2000).

This is a table that shows the elemental chemical composition of the Earth's crust. They will vary depending on the way they were calculated and the source. $98.5 \%$ of the Earth's crust consists of oxygen, silicon, aluminum, iron, calcium, sodium, potassium and magnesium. All other elements account for approximately $1.5 \%$ of the volume of the Earth's crust.

\section{The some characteristics of minerals}

The physical properties of a mineral are determined by its chemical composition and its crystalline structure. Within the limits of the permissible variation in chemical composition, 
different samples of a single mineral species are expected to display the same set of physical properties. These characteristic physical properties are therefore very useful to the field geologist in identifying and describing a specimen (Zoltai \& Stout,1984).

Properties which describe the physical appearance of a mineral specimen include color, streak, and luster. Mass-dependent properties include density; mechanical properties include hardness, cleavage, fracture, and tenacity. Properties relating to the growth patterns and physical appearance of crystals, both individually and in aggregate, are described in terms of crystal habit, crystal form, and crystal system (Klein \& Hurlbut, 1985).

1. Crystal form and habit (shape).

2. Luster and transparency

3. Color and streak.

4. Cleavage, fracture, and parting.

5. Tenacity

6. Density

7. Hardness

\subsection{Crystal form and habit}

The crystal faces developed on a specimen may arise either as a result of growth or of cleavage. In either case, they reflect the internal symmetry of the crystal structure that makes the mineral unique. The crystal faces commonly seen on quartz are growth faces and represent the slow est growing directions in the structure. Quartz grows rapidly along its caxis (three-fold or trigonal symmetry axis) direction and so never shows faces perpendicular to this direction. On the other hand, calcite rhomb faces and mica plates are cleavages and represent the weakest chemical bonds in the structure. There is a complex terminology for crystal faces, but some obvious names for faces are prisms and pyramids. A prism is a face that is perpendicular to a major axis of the crystal, whereas a pyramid is one that is not perpendicular to any major axis.

Crystals that commonly develop prism faces are said to have a prismatic or columnar habit. Crystals that grow in fine needles are acicular; crystals growing flat plates are tabular. Crystals forming radiating sprays of needles or fibers are stellate. Crystals forming parallel fibers are fibrous, and crystals forming branching, tree-like growths are dendritic.

\subsection{Luster and transparency}

The way a mineral transmits or reflects light is a diagnostic property. The transparency may be either opaque, translucent, or transparent. This reflectance property is called luster. Native metals and many sulfides are opaque and reflect most of the light hitting their surfaces and have a metallic luster. Other opaque or nearly opaque oxides may appear dull, or resinous. Transparent minerals with a high index of refraction such as diamond appear brilliant and are said to have an adamantine luster, whereas those with a lower index of refraction such as quartz or calcite appear glassy and are said to have a vitreous luster.

\subsection{Color and streak}

Color is fairly self-explanatory property describing the reflectance. Metallic minerals are either white, gray, or yellow. The presence of transition metals with unfilled electron shells 
(e.g. V, Cr, $\mathrm{Mn}, \mathrm{Fe}, \mathrm{Co}, \mathrm{Ni}$, and $\mathrm{Cu}$ ) in oxide and silicate minerals causes them to be opaque or strongly colored so that the streak, the mark that they leave when scratched on a white ceramic tile, will also be strongly colored.

\subsection{Cleavage, fracture, and parting}

Because bonding is not of equal strength in all directions in most crystals, they will tend to break along crystallographic directions giving them a fracture property that reflects the underlying structure and is frequently diagnostic. A perfect cleavage results in regular flat faces resembling growth faces such as in mica, or calcite. A less well developed cleavage is said to be imperfect, or if very weak, a parting. If a fracture is irregular and results in a rough surface, it is hackly. If the irregular fracture propagates as a single surface resulting in a shiny surface as in glass, the fracture is said to be conchoidal.

\subsection{Tenacity}

Tenacity is the ability of a mineral to deform plastically under stress. Minerals may be brittle, that is, they do not deform, but rather fracture, under stress as do most silicates and oxides. They may be sectile, or be able to deform so that they can be cut with a knife. Or, they may be ductile and deform readily under stress as does gold.

\subsection{Density}

Density is a well-defined physical property measured in $\mathrm{g} / \mathrm{cm}^{3}$. Most silicates of light element have densities in the range 2.6 to 3.5. Sulfides are typically 5 to 6 . Iron metal about 8 , lead about 13 , gold about 19 , and osmium, the densest substance, and a native element mineral is 22 .

\subsection{Hardness}

Hardness is usually tested by seeing if some standard minerals are able to scratch others. A standard scale was developed by Friedrich Mohs in 1812. The standard minerals making up the Mohs scale of hardness are:
1. Talc
6. Orthoclase
2. Gypsum
7. Quartz
3. Calcite
8. Topaz
4. Fluorite
9. Corundum
5. Apatite
10 Diamond

This scale is approximately linear up to corundum, but diamond is approximately 5 times harder than corundum.

\subsection{Unique properties}

A few minerals may have easily tested unique properties that may greatly aid identification. For example, halite $(\mathrm{NaCl})$ (common table salt) and sylvite $(\mathrm{KCl})$ are very similar in most of their physical properties, but have a distinctly different taste on the tongue, with sylvite having a more bitter taste. Another unique property that can be used to distinguish between 
otherwise similar back opaque minerals is magnetism. For example, magnetite $\left(\mathrm{Fe}_{3} \mathrm{O}_{4}\right)$, ilmenite $\left(\mathrm{FeTiO}_{3}\right)$, and pyrolusite $\left(\mathrm{MnO}_{2}\right)$ are all dense, black, opaque minerals which can easily be distinguished by testing the magnetism with a magnet. Magnetite is strongly magnetic and can be permanently magnetized to form a lodestone; ilmenite is weakly magnetic; and pyrolusite is not magnetic at all.

\subsection{Other properties}

There are numerous other properties that are diagnostic of minerals, but which generally require more sophisticated devices to measure or detect. For example, minerals containing the elements $\mathrm{U}$ or $\mathrm{Th}$ are radioactive, and this radioactivity can be easily detected with a Geiger counter. Examples of radioactive minerals are uraninite $\left(\mathrm{UO}_{2}\right)$, thorite $\left(\mathrm{ThSiO}_{4}\right)$, and carnotite $\left(\mathrm{K}_{2}\left(\mathrm{UO}_{2}\right)\left(\mathrm{VO}_{4}\right)_{2} \mathrm{rH}_{2} \mathrm{O}\right)$. Some minerals may also be fluorescent under ultraviolet light, that is they absorb UV lighta and emit in the visible. Other optical properties such as index of refraction and pleochroism (differential light absorption) require an optical microscope to measure. Electrical conductivity is an important physical property but requires an impedance bridge to measure. In general native metals are good conductors, sulfides of transition metals are semi-conductors, whereas most oxygen-bearing minerals (i.e., silicates, carbonates, oxides, etc.) are insulators. Additionally, quartz $\left(\mathrm{SiO}_{2}\right)$ is piezoelectric (develops an electrical charge at opposite end under an applied mechanical stress); and tourmaline is pyroelectric (develops an electrical charge at opposite end under an applied thermal gradient).

\section{Mineral occurences and environments}

In addition to physical properties, one of the most diagnostic features of a mineral is the geological environment in which it is occurs (Deer, Howie \& Zussman, 1992).

\subsection{Igneous minerals}

Minerals in igneous rocks must have high melting points and be able to co-exist with, or crystallize from, silicate melts at temperatures above $800^{\circ} \mathrm{C}$. Igneous rocks can be generally classed according to their silica content with low-silica $\left(<50 \% \mathrm{SiO}_{2}\right)$ igneous rocks being termed basic or mafic, and high-silica igneous rocks being termed silicic or acidic. Basic igneous rocks (BIR) include basalts, dolerites, gabbros, kimberlites, and peridotites, and abundant minerals in such rocks include olivine, pyroxenes, Ca-feldspar (plagioclase), amphiboles, and biotite. The abundance of Fe in these rocks causes them to be dark-colored. Silicic igneous rocks (SIR) include granites, granodiorites, and rhyolites, and abundant minerals include quartz, muscovite, and alkali feldspars. These are commonly light-colored although color is not always diagnostic. In addition to basic and silicic igneous rocks, a third igneous mineral environment representing the final stages of igneous fractionation is called a pegmatite (PEG) which is typically very coarse-grained and similar in composition to silicic igneous rocks (i.e. high in silica). Elements that do not readily substitute into the abundant minerals are called incompatible elements, and these typically accumulate to form their own minerals in pegmatites. Minerals containing the incompatible elements, $\mathrm{Li}, \mathrm{Be}, \mathrm{B}$, $\mathrm{P}, \mathrm{Rb}, \mathrm{Sr}, \mathrm{Y}, \mathrm{Nb}$, rare earths, $\mathrm{Cs}$, and Ta are typical and characteristic of pegmatites. 


\subsection{Metamorphic minerals}

Minerals in metamorphic rocks have crystallized from other minerals rather than from melts and need not be stable to such high temperatures as igneous minerals. In a very general way, metamorphic environments may be classified as low-grade metamorphic (LGM) (temperatures of $60^{\circ}$ to $400^{\circ} \mathrm{C}$ and pressures $<.5 \mathrm{GPa}(=15 \mathrm{~km}$ depth) and high-grade meta morphic (HGM) (temperatures $>400^{\circ}$ and/or pressures $\left.>.5 \mathrm{GPa}\right)$. Minerals characteristic of low- grade metamorphic environments include the zeolites, chlorites, and andalusite. Minerals characteristic of high grade metamorphic environments include sillimanite, kyanite, staurolite, epidote, and amphiboles.

\subsection{Sedimentary minerals}

Minerals in sedimentary rocks are either stable in low-temperature hydrous environments (e.g. clays) or are high temperature minerals that are extremely resistant to chemical weathering (e.g. quartz). One can think of sedimentary minerals as exhibiting a range of solubilities so that the most insoluble minerals such as quartz, gold, and diamond accumulate in the coarsest detrital sedimentary rocks, less resistant minerals such as feldspars, which weather to clays, accumulate in finer grained siltstones and mudstones, and the most soluble minerals such as calcite and halite (rock-salt) are chemically precipitated in evaporite deposits. Sedimentary minerals can classify into detrital sediments (DSD) and evaporites (EVP). Detrital sedimentary minerals include quartz, gold, diamond, apatite and other phosphates, calcite, and clays. Evaporite sedimentary minerals include calcite, gypsum, anhydrite, halite and sylvite, plus some of the borate minerals.

\subsection{Hydrothermal minerals}

The fourth major mineral environment is hydrothermal, minerals precipitated from hot aqueous solutions associated with emplacement of intrusive igneous rocks. This environment is commonly grouped with metamorphic environments, but the minerals that form by this process and the elements that they contain are so distinct from contact or regional metamorphic rocks that it us useful to consider them as a separate group. These may be sub-classified as high temperature hydrothermal (HTH), low temperature hydrothermal (LTH), and oxydized hydrothermal (OXH). Sulfides may occur in igneous and metamorphic rocks, but are most typically hydrothermal. High temperature hydrothermal minerals include gold, silver, tungstate minerals, chalcopyrite, bornite, the tellurides, and molybdenite. Low temperature hydrothermal minerals include barite, gold, cinnabar, pyrite, and cassiterite. Sulfide minerals are not stable in atmospheric oxygen and will weather by oxidation to form oxides, sulfates and carbonates of the chalcophile metals, and these minerals are characteristic of oxidized hydrothermal deposits. Such deposits are called gossans and are marked by yellow-red iron oxide stains on rock surfaces. These usually mark mineralized zones at depth.

\section{The mineral classification}

Minerals are classified on their chemistry, particularly on the anionic element or polyanionic group of elements that occur in the mineral. An anion is a negatively charge atom, and a 
polyanion is a strongly bound group of atoms consisting of a cation plus several anions (typically oxygen) that has a net negative charge.

For example carbonate $\left(\mathrm{CO}_{3}\right)^{2-}$, silicate $\left(\mathrm{SiO}_{4}\right)^{4-}$ are common polyanions. This classification has been successful because minerals rarely contain more than one anion or polyanion, whereas they typically contain several different cations (Nesse, 2000).

\subsection{Native elements}

The first group of minerals is the native elements, and as pure elements, these minerals contain no anion or polyanion. Native elements such as gold $(\mathrm{Au})$, silver $(\mathrm{Ag})$, copper $(\mathrm{Cu})$, and platinum $(\mathrm{Pt})$ are metals, graphite is a semi-metal, and diamond $(\mathrm{C})$ is an insulator.

\subsection{Sulfides}

The sulfides contain sulfur (S) as the major "anion". Although sulfides should not be considered ionic, the sulfide minerals rarely contain oxygen, so these minerals form a chemically distinct group. Examples are pyrite $\left(\mathrm{FeS}_{2}\right)$, sphalerite $(\mathrm{ZnS})$, and galena $(\mathrm{PbS})$. Minerals containing the elements As, Se, and Te as "anions" are also included in this group.

\subsection{Halides}

The halides contain the halogen elements $(\mathrm{F}, \mathrm{Cl}, \mathrm{Br}$, and I) as the dominant anion. These minerals are ionically bonded and typically contain cations of alkali and alkaline earth ele ments $(\mathrm{Na}, \mathrm{K}$, and $\mathrm{Ca})$. Familiar examples are halite $(\mathrm{NaCl})$ (rock salt) and fluorite $\left(\mathrm{CaF}_{2}\right)$.

\subsection{Oxides}

The oxide minerals contain various cations (not associated with a polyanion) and oxygen. Examples are hematite $\left(\mathrm{Fe}_{2} \mathrm{O}_{3}\right)$ and magnetite $\left(\mathrm{Fe}_{3} \mathrm{O}_{4}\right)$.

\subsection{Hydroxides}

These minerals contain the polyanion $\mathrm{OH}$ - as the dominant anionic species. Examples include brucite $\left(\mathrm{Mg}(\mathrm{OH})_{2}\right)$ and gibbsite $\left(\mathrm{Al}(\mathrm{OH})_{3}\right)$.

\subsection{Carbonates}

The carbonates contain $\mathrm{CO}_{3}{ }^{2-}$ as the dominant polyanion in which $\mathrm{C}^{4+}$ is surrounded by three $\mathrm{O}^{2-}$ anions in a planar triangular arrangement. A familiar example is calcite $\left(\mathrm{CaCO}_{3}\right)$. Because $\mathrm{NO}_{3}^{-}$shares this geometry, the nitrate minerals such as soda niter (nitratite) $\left(\mathrm{NaNO}_{3}\right)$ are included in this group.

\subsection{Sulfates}

These minerals contain $\mathrm{SO}_{4}{ }^{2-}$ as the major polyanion in which $\mathrm{S}^{6+}$ is surrounded by four oxygen atoms in a tetrahedron. Note that this group is distinct from sulfides which contain no O. A familiar example is gypsum $\left(\mathrm{CaSO}_{4} \cdot 2 \mathrm{H}_{2} \mathrm{O}\right)$. 


\subsection{Phosphates}

The phosphates contain tetrahedral $\mathrm{PO}_{4}^{3-}$ groups as the dominant polyanion. A common example is apatite $\left(\mathrm{Ca}_{5}\left(\mathrm{PO}_{4}\right)_{3}(\mathrm{OH})\right)$ a principal component of bones and teeth. The other trivalent tetrahedral polyanions, arsenate $\mathrm{AsO}_{4}{ }^{3-}$, and vanadate $\mathrm{VO}_{4}{ }^{3-}$ are structurally and chemically similar and are included in this group.

\subsection{Borates}

The borates contain triangular $\mathrm{BO}_{3}^{3-}$ or tetrahedral $\mathrm{BO}_{4}{ }^{5-}$, and commonly both coordinations may occur in the same mineral. A common example is borax, $\left(\mathrm{Na}_{2} \mathrm{BIII}_{2} \mathrm{BIV}_{2} \mathrm{O}_{5}(\mathrm{OH})_{4} 8 \mathrm{H}_{2} \mathrm{O}\right)$.

\subsection{Silicates}

This group of minerals contains $\mathrm{SiO}_{4}^{4-}$ as the dominant polyanion. In these minerals the $\mathrm{Si}^{4+}$ cation is always surrounded by 4 oxygens in the form of a tetrahedron. Because $\mathrm{Si}$ and $\mathrm{O}$ are the most abundant elements in the Earth, this is the largest group of minerals and is divided into subgroups based on the degree of polymerization of the $\mathrm{SiO}_{4}$ tetrahedra.

\subsubsection{Orthosilicates}

These minerals contain isolated $\mathrm{SiO}_{4}^{4-}$ polyanionic groups in which the oxygens of the polyanion are bound to one $\mathrm{Si}$ atom only, i.e., they are not polymerized. Examples are forsterite (Mg-olivine, $\mathrm{Mg}_{2} \mathrm{SiO}_{4}$ ), and pyrope (Mg-garnet, $\mathrm{Mg}_{3} \mathrm{Al}_{2} \mathrm{Si}_{3} \mathrm{O}_{12}$ ).

\subsubsection{Sorosilicates}

These minerals contain double silicate tetrahedra in which one of the oxygens is shared with an adjacent tetrahedron, so that the polyanion has formula $\left(\mathrm{Si}_{2} \mathrm{O}_{7}\right)^{6-}$. An example is epidote $\left(\mathrm{Ca}_{2} \mathrm{Al}_{2} \mathrm{FeO}(\mathrm{OH}) \mathrm{SiO}_{4} \mathrm{Si}_{2} \mathrm{O}_{7}\right)$, a mineral common in metamorphic rocks.

\subsubsection{Cyclosilicates}

These minerals contain typically six-membered rings of silicate tetrahedra with formula $\left(\mathrm{Si}_{6} \mathrm{O}_{17}\right)^{10-}$. An example is tourmaline.

\subsubsection{Chain silicates}

These minerals contain $\mathrm{SiO}_{4}$ polyhedra that are polymerized in one direction to form chains. They may be single chains, so that of the four oxygen coordinating the Si atom, two are shared with adjacent tetrahedra to form an infinite chain with formula $\left(\mathrm{SiO}_{3}\right)^{2-}$. The single chain silicates include the pyroxene and pyroxenoid minerals which are common constituents of igneous rocks. Or they may form double chains with formula $\left(\mathrm{Si}_{4} \mathrm{O}_{11}\right)^{8-}$, as in the amphibole minerals, which are common in metamorphic rocks.

\subsubsection{Sheet silicates}

These minerals contain $\mathrm{SiO}_{4}$ polyhedra that are polymerized in two dimensions to form sheets with formula $\left(\mathrm{Si}_{4} \mathrm{O}_{10}\right)^{4-}$. Common examples are the micas in which the cleavage reflects the sheet structure of the mineral. 


\subsubsection{Framework silicates}

These minerals contain $\mathrm{SiO}_{4}$ polyhedra that are polymerized in three dimensions to form a framework with formula $\left(\mathrm{SiO}_{2}\right)$. Common examples are quartz $\left(\mathrm{SiO}_{2}\right)$ and the feldspars $\left(\mathrm{NaAlSi}_{3} \mathrm{O}_{8}\right)$ which are the most abundant minerals in the Earth's crust. In the feldspars $\mathrm{Al}^{3+}$ may substitute for $\mathrm{Si}^{4+}$ in the tetrahedra, and the resulting charge imbalance is compensated by an alkali cation ( $\mathrm{Na}$ or $\mathrm{K}$ ) in interstices in the framework.

\section{The classification of crystals}

The descriptive terminology of the discipline of crystallography is applied to crystals in order to describe their structure, symmetry, and shape. This terminology describes the crystal lattice, which provides a mineral with its ordered internal structure. It also describes and analyzes various types of symmetry. By considering what type of symmetry a mineral species possesses, the species may be categorized as a member of one of six crystal systems and one of thirty-two crystal classes.

The concept of symmetry describes the periodic repetition of structural features. Two general types of symmetry exist. These include translational symmetry and point symmetry. Translational symmetry describes the periodic repetition of a motif across a length or through an area or volume. Point symmetry, on the other hand, describes the periodic repetition of a motif about a single point. Reflection, rotation, inversion, and rotoinversion are all point symmetry operations.

A specified motif which is translated linearly and repeated many times will produce a lattice. A lattice is an array of points which define a repeated spatial entity called a unit cell. The unit cell of a lattice is the smallest unit which can be repeated in three dimensions in order to construct the lattice.

The number of possible lattices is limited. In the plane only five different lattices may be produced by translation. The French crystallographer Auguste Bravais (1811-1863) established that in three-dimensional space only fourteen different lattices may be constructed. These fourteen different lattices are thus termed the Bravais lattices.

The reflection, rotation, inversion, and rotoinversion symmetry operations may be combined in a variety of different ways. There are thirty-two possible unique combinations of symmetry operations. Minerals possessing the different combinations are therefore categorized as members of thirty-two crystal classes. In this classificatory scheme each crystal class corresponds to a unique set of symmetry operations. Each of the crystal classes is named according to the variant of a crystal form which it displays. Each crystal class is grouped as one of the six different crystal systems according to which characteristic symmetry operation it possesses.

A crystal form is a set of planar faces which are geometrically equivalent and whose spatial positions are related to one another by a specified set of symmetry operations. If one face of a crystal form is defined, the specified set of point symmetry operations will determine all of the other faces of the crystal form. A simple crystal may consist of only a single crystal form. A more complicated crystal may be a combination of several different forms. Example crystal forms are the parallelohedron, prism, pyramid, trapezohedron, rhombohedron and tetrahedron. 
Each crystal class is a member of one of six crystal systems. These include the isometric, hexagonal, tetragonal, orthorhombic, monoclinic, and triclinic crystal systems. Every crystal of a certain crystal system shares a characteristic symmetry element - for example, a certain axis of rotational symmetry - with the other members of its system. The crystal system of a mineral species may sometimes be determined by examining a particularly well-formed crystal of the species (Nesse, 2004).

\section{The economic value of minerals}

Minerals that are of economic value can be classified as metallic or nonmetallic. Metallic minerals are those from which valuable metals (e.g. iron, copper) can be extracted for commercial use. Metals that are considered geochemically abundant occur at crustal abundances of 0.1 percent or more (e.g. iron, aluminum, manganese, magnesium, titanium). Metals that are considered geochemically scarce occur at crustal abundances of less than 0.1 percent (e.g. nickel, copper, zinc, platinum metals). Some important metallic minerals are: hematite (a source of iron), bauxite (a source of aluminum), sphalerite (a source of zinc) and galena (a source of lead). Metallic minerals occasionally but rarely occur as a single element (e.g. native gold or copper).

Nonmetallic minerals are valuable, not for the metals they contain, but for their properties as chemical compounds. Because they are commonly used in industry, they are also often referred to as industrial minerals. They are classified according to their use. Some industrial minerals are used as sources of important chemicals (e.g. halite for sodium chloride and borax for borates). Some are used for building materials (e.g. gypsum for plaster and kaolin for bricks). Others are used for making fertilizers (e.g. apatite for phosphate and sylvite for potassium). Still others are used as abrasives (e.g. diamond and corrundum).

\subsection{Mineral deposits}

Minerals are everywhere around us. For example, the ocean is estimated to contain more than 70 million tons of gold. Yet, it would be much too expensive to recover that gold because of its very low concentration in the water. Minerals must be concentrated into deposits to make their collection economically feasible. A mineral deposit containing one or more minerals that can be extracted profitably is called an ore. Many minerals are commonly found together (e.g. quartz and gold; molybdenum, tin and tungsten; copper, lead and zinc; platinum and palladium). Because various geologic processes can create local enrichments of minerals, mineral deposits can be classified according to the concentration process that formed them. The five basic types of mineral deposits are: hydrothermal, magmatic, sedimentary, placer and residual.

Hydrothermal mineral deposits are formed when minerals are deposited by hot, aqueous solutions flowing through fractures and pore spaces of crustal rock. Many famous ore bodies have resulted from hydrothermal depositon, including the tin mines in Cornwall, England and the copper mines in Arizona and Utah, USA. Magmatic mineral deposits are formed when processes such as partial melting and fractional crystallization occur during the melting and cooling of rocks. 
Pegmatite rocks formed by fractional crystallization can contain high concentrations of lithium, beryllium and cesium. Layers of chromite (chrome ore) were also formed by igneous processes in the famous Bushveld Igneous Complex in South Africa.

Several mineral concentration processes involve sedimentation or weathering. Water soluble salts can form sedimentary mineral deposits when they precipitate during evaporation of lake or seawater (evaporite deposits). Important deposits of industrial minerals were formed in this manner, including the borax deposits at Death Valley and Searles Lake, and the marine deposits of gypsum found in many states.

Minerals with a high specific gravity (e.g. gold, platinum, diamonds) can be concentrated by flowing water in placer deposits found in stream beds and along shorelines. The most famous gold placer deposits occur in the Witwatersrand basin of South Africa. Residual mineral deposits can form when weathering processes remove water soluble minerals from an area, leaving a concentration of less soluble minerals. The aluminum ore, bauxite, was originally formed in this manner under tropical weathering conditions. The best known bauxite deposit in the United States occurs in Arkansas.

\subsection{Mineral utilization}

Minerals are not evenly distributed in the earth's crust. Mineral ores are found in just a relatively few areas, because it takes a special set of circumstances to create them. Therefore, the signs of a mineral deposit are often small and difficult to recognize. Locating deposits requires experience and knowledge. Geologists can search for years before finding an economic mineral deposit. Deposit size, its mineral content, extracting efficiency, processing costs and market value of the processed minerals are all factors that determine if a mineral deposit can be profitably developed. For example, when the market price of copper increased significantly in the 1970s, some marginal or low-grade copper deposits suddenly became profitable ore bodies. After a potentially profitable mineral deposit is located, it is mined by one of several techniques. Which technique is used depends upon the type of deposit and whether the deposit is shallow and thus suitable for surface mining or deep and thus requiring sub-surface mining.

Surface mining techniques include: open-pit mining, area strip mining, contour strip mining and hydraulic mining. Open-pit mining involves digging a large, terraced hole in the ground in order to remove a near-surface ore body. This technique is used in copper ore mines in Arizona and Utah and iron ore mines in Minnesota, USA. Area strip mining is used in relatively flat areas. The overburden of soil and rock is removed from a large trench in order to expose the ore body. After the minerals are removed, the old trench is filled and a new trench is dug. This process is repeated until the available ore is exhausted. Contour strip mining is a similar technique except that it is used on hilly or mountainous terrains. A series of terraces are cut into the side of a slope, with the overburden from each new terrace being dumped into the old one below.

Hydraulic mining is used in places such as the Amazon in order to extract gold from hillsides. Powerful, high-pressure streams of water are used to blast away soil and rock containing gold, which is then separated from the runoff. This process is very damaging to the environment, as entire hills are eroded away and streams become clogged with sediment. If land subjected to any of these surface mining techniques is not properly 
restored after its use, then it leaves an unsightly scar on the land and is highly susceptible to erosion.

Some mineral deposits are too deep to be surface mined and therefore require a sub-surface mining method. In the traditional sub surface method a deep vertical shaft is dug and tunnels are dug horizontally outward from the shaft into the ore body. The ore is removed and transported to the surface. The deepest such subsurface mines (deeper than $3500 \mathrm{~m}$ ) in the world are located in the Witwatersrand basin of South Africa, where gold is mined. This type of mining is less disturbing to the land surface than surface mining. It also usually produces fewer waste materials. However, it is more expensive and more dangerous than surface mining methods.

A newer form of subsurface mining known as in-situ mining is designed to coexist with other land uses, such as agriculture. An in-situ mine typically consists of a series of injection wells and recovery wells built with acid-resistant concrete and polyvinyl chloride casing. A weak acid solution is pumped into the ore body in order to dissolve the minerals. Then, the metal-rich solution is drawn up through the recovery wells for processing at a refining facility. This method is used for the in-situ mining of copper ore.

Once an ore has been mined, it must be processed to extract pure metal. Processes for extracting metal include smelting, electrowinning and heap leaching. In preparation for the smelting process, the ore is crushed and concentrated by a flotation method. The concentrated ore is melted in a smelting furnace where impurities are either burned-off as gas or separated as molten slag. This step is usually repeated several times to increase the purity of the metal. For the electrowinning method ore or mine tailings are first leached with a weak acid solution to remove the desired metal. An electric current is passed through the solution and pure metal is electroplated onto a starter cathode made of the same metal. Copper can be refined from oxide ore by this method. In addition, copper metal initially produced by the smelting method can be purified further by using a similar electrolytic procedure. Gold is sometimes extracted from ore by the heap leaching process. A large pile of crushed ore is sprayed with a cyanide solution. As the solution percolates through the ore it dissolves the gold. The solution is then collected and the gold extracted from it. All of the refining methods can damage the environment. Smelters produce large amounts of air pollution in the form of sulfur dioxide which leads to acid rain. Leaching methods can pollute streams with toxic chemicals that kill wildlife (Roberts, Campbell \& Rapp, 1990).

\subsection{Mineral sufficiency and the future}

Mineral resources are essential to life as we know it. A nation cannot be prosperous without a reliable source of minerals, and no country has all the mineral resources it requires. The United States has about 5 percent of the world's population and 7 percent of the world's land area, but uses about 30 percent of the world's mineral resources. It imports a large percentage of its minerals; in some cases sufficient quantities are unavailable in the U.S., and in others they are cheaper to buy from other countries. Certain minerals, particularly those that are primarily imported and considered of vital importance, are stockpiled by the United States in order to protect against embargoes or other political crises. These strategic minerals include: bauxite, chromium, cobalt, manganese and platinum. 
Because minerals are produced slowly over geologic time scales, they are considered nonrenewable resources. The estimated mineral deposits that are economically feasible to mine are known as mineral reserves. The growing use of mineral resources throughout the world raises the question of how long these reserves will last. Most minerals are in sufficient supply to last for many years, but a few (e.g. gold, silver, lead, tungsten and zinc) are expected to fall short of demand in the near future. Currently, reserves for a particular mineral usually increase as the price for that mineral increases. This is because the higher price makes it economically feasible to mine some previously unprofitable deposits, which then shifts these deposits to the reserves. However, in the long term this will not be the case because mineral deposits are ultimately finite.

There are ways to help prolong the life of known mineral reserves. Conservation is an obvious method for stretching reserves. If you use less, you need less. Recycling helps increase the amount of time a mineral or metal remains in use, which decreases the demand for new production. It also saves considerable energy, because manufacturing products from recycled metals (e.g. aluminum, copper) uses less energy than manufacturing them from raw materials. As a result, mineral prices are kept artificially low which discourages conservation and recycling.

\section{References}

Blackburn, W.H., Dennen, W.H. (1988). Principles of Mineralogy. (1st edition), Wm.C. Brown Publishers, ISBN 069715078X, Dubuque, Iowa.

Deer, W.A., Howie, R.A., Zussman, J. (1992). An Introduction to the Rock Forming Minerals. (2nd edition), ISBN 0-582-30094-0, Longman Publishing Co, London.

Klein, C., Hurlbut, Jr.C.S. (1985). Manual of Mineralogy. (20th edition), John Wiley \& Sons, ISBN 047180580, New York.

Lutgens, F.K. and Tarbuck, E.J. (2000). Essentials of Geology. (7th edition), Prentice Hall, ISBN, 0130145440, New York.

Nesse, W.D. (2000). Introduction to mineralogy. Oxford University Press, ISBN-10: 0195106911; New York.

Nesse, W. D. (2004). Introduction to Optical Mineralogy. Oxford University Press, ISBN 019522132X, New York.

Roberts, W.L., Campbell, T.J., Rapp, Jr. G.R. (1990). Encyclopedia of Minerals. (2nd edition), Van Nostrand, Reinhold, New York.

Rudnick, R.L., Fountain, M.D. (1995). Nature and composition of the continental crust: A lower crustal perspective. Reviews of geophysics, Vol. 33, No. 3, pp. 267-309.

Zoltai, T., Stout, J.H. (1984). Mineralogy: Concepts and Principles. Burgess Publishing Co, ISBN 9780024320100, Minneapolis. 


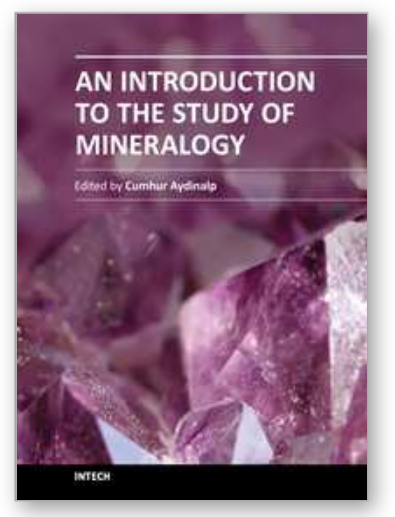

\author{
An Introduction to the Study of Mineralogy \\ Edited by Prof. Cumhur Aydinalp
}

ISBN 978-953-307-896-0

Hard cover, 154 pages

Publisher InTech

Published online 01, February, 2012

Published in print edition February, 2012

An Introduction to the Study of Mineralogy is a collection of papers that can be easily understood by a wide variety of readers, whether they wish to use it in their work, or simply to extend their knowledge. It is unique in that it presents a broad view of the mineralogy field. The book is intended for chemists, physicists, engineers, and the students of geology, geophysics, and soil science, but it will also be invaluable to the more advanced students of mineralogy who are looking for a concise revision guide.

\title{
How to reference
}

In order to correctly reference this scholarly work, feel free to copy and paste the following:

Cumhur Aydinalp (2012). An Introduction to Mineralogy, An Introduction to the Study of Mineralogy, Prof. Cumhur Aydinalp (Ed.), ISBN: 978-953-307-896-0, InTech, Available from:

http://www.intechopen.com/books/an-introduction-to-the-study-of-mineralogy/an-introduction-to-mineralogy

\section{INTECH}

open science | open minds

\author{
InTech Europe \\ University Campus STeP Ri \\ Slavka Krautzeka 83/A \\ 51000 Rijeka, Croatia \\ Phone: +385 (51) 770447 \\ Fax: +385 (51) 686166 \\ www.intechopen.com
}

\author{
InTech China \\ Unit 405, Office Block, Hotel Equatorial Shanghai \\ No.65, Yan An Road (West), Shanghai, 200040, China \\ 中国上海市延安西路65号上海国际贵都大饭店办公楼 405 单元 \\ Phone: +86-21-62489820 \\ Fax: $+86-21-62489821$
}


(C) 2012 The Author(s). Licensee IntechOpen. This is an open access article distributed under the terms of the Creative Commons Attribution 3.0 License, which permits unrestricted use, distribution, and reproduction in any medium, provided the original work is properly cited. 